\title{
Research on Hydraulic Loom Wastewater Using the Combined Process Containing Coagulation- Ozonation- Flotation Treatment
}

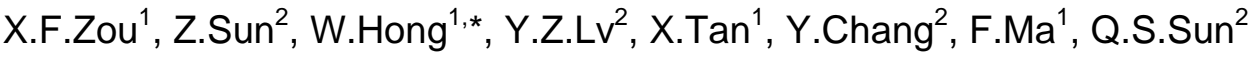 \\ ${ }^{1}$ Shandong Academy of Environmental Science, Jinan, Shandong, China \\ ${ }^{2}$ Bashan Group Co., Ltd,Zibo, Shandong, China \\ *email: honw@163.com
}

Keywords: Hydraulic loom wastewater; Coagulation; Ozonation; Flotation

Abstract. In this study, the characteristic of $\mathrm{COD}_{\mathrm{Cr}}$ distribution in hydraulic loom wastewater was investigated. The results show that most of $\mathrm{COD}_{\mathrm{Cr}}$ materials exist in mesocolloid and suspending forms. Suspending and mesocolloid organics accounted for $31.5 \%$ and $46.9 \%$ of the total $\mathrm{COD}_{\mathrm{Cr}}$, respectively. The hydraulic loom wastewater was treated by the method of coagulation- ozonationflotation process, and the results show that the optimal dosage of $\mathrm{Al}_{2}\left(\mathrm{SO}_{4}\right)_{3}$ and ozone is $250 \mathrm{mg} / \mathrm{L}$ and $30 \mathrm{mg} / \mathrm{L}$, in which conditions the removal efficiency of $\mathrm{COD}_{\mathrm{Cr}}$ can reach to $87.0 \%$. When the $\mathrm{COD}_{\mathrm{Cr}}$ and turbidity of influent were $214 \mathrm{mg} / \mathrm{L}$ and $63.9 \mathrm{NTU}$, the corresponding effluent indexes can be reduced to $27.8 \mathrm{mg} / \mathrm{L}$ and $2.5 \mathrm{NTU}$, and the turbidity removal rate was $96.1 \%$.

\section{Introduction}

Hydraulic loom achieves high production levels and quality, and is the fastest developed shuttleless loom in recent years. The disadvantage of hydraulic loom is that during production, it consumes large amounts of water. Nearly 450 million tons of water was used annually on the hydraulic loom in China at present[1]. Wastewater of hydraulic loom contains kinds of textile sizing agent, including cotton, acrylate and butyl acrylate. The characteristic of hydraulic loom wastewater is chemically complex and high-content of gel[2]. The hydraulic loom wastewater is moderate pollution wastewater, and with appropriate treatment, most of it can be recovery, which has important practical significance for reducing wastewater emissions and saving water resources.

In a typical process of water treatment for hydraulic loom wastewater is coagulation air floatation method[3]. Many studies have found that ozone can change the properties of suspended particles in the process of treatment, and then improve the removal efficiency of flocculation[4,5]. In this study, the characteristics of hydraulic loom wastewater were considered, and the process of coagulation-ozone-flotation was conducted as the treatment. The optimal coagulant and dosage of ozone, optimal of conditions of treatment were studied, and the aim of the present work was to determine the technical guidance for the treatment of hydraulic loom wastewater.

\section{Materials and Methods}

Experimental materials and technology.Hydraulic loom wastewater was taken from a textile factory in zibo in shandong province.Table 1 shows the main pollutants of the effluent. Process was shown in Fig.1.

Table 1 The water indexes of hydraulic loom wastewater used in the experiments

\begin{tabular}{cccccc}
\hline $\begin{array}{c}\text { Pollutant } \\
\text { index }\end{array}$ & $\mathrm{pH}$ & $\begin{array}{c}\mathrm{COD}_{\mathrm{Cr}} \\
(\mathrm{mg} / \mathrm{L})\end{array}$ & $\begin{array}{c}\mathrm{NH}_{4}{ }^{+}-\mathrm{N} \\
(\mathrm{mg} / \mathrm{L})\end{array}$ & $\begin{array}{c}\mathrm{SS} \\
(\mathrm{mg} / \mathrm{L})\end{array}$ & $\begin{array}{c}\text { Turbidity } \\
(\mathrm{NTU})\end{array}$ \\
\hline value & $7.5 \sim 8.0$ & $200 \sim 290$ & $1.5 \sim 3.5$ & $110 \sim 210$ & $63 \sim 86$ \\
\hline
\end{tabular}




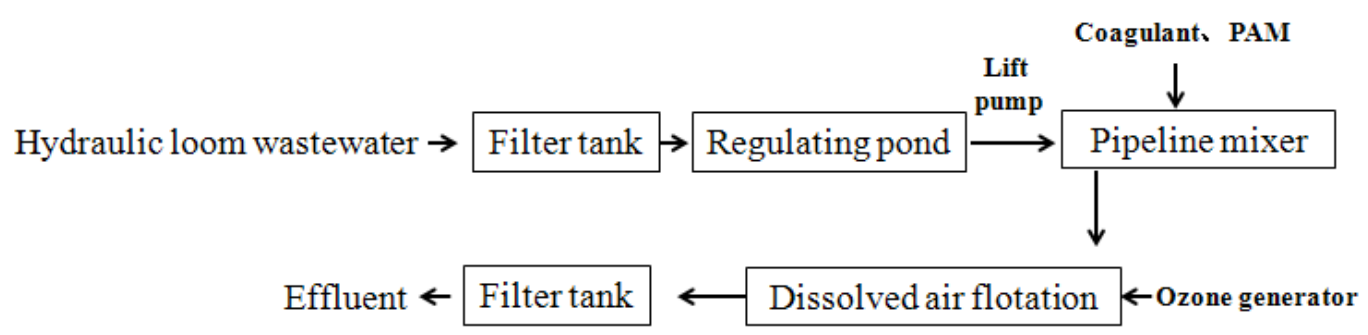

Fig. 1 Schematic Diagram of Process

Water quality characteristics of wastewater.In order to understand the characteristics of hydraulic loom wastewater, and also define the distribution of $\mathrm{COD}_{\mathrm{Cr}}$ in the suspended state, the near gel state and the dissolved state. The distribution of $\mathrm{COD}_{\mathrm{Cr}}$ in the suspending, the mesocolloid and the dissolved organics is separated and defined according to the following methods: wastewater after filters remove $\mathrm{COD}_{\mathrm{Cr}}$ is the suspended state, and then through $0.45 \mu \mathrm{m}$ filter membrane filtration, the removal of $\mathrm{COD}_{\mathrm{Cr}}$ is mesocolloid, and the $\mathrm{COD}_{\mathrm{Cr}}$ in the filtrate is dissolved organics.

Comparison of difference kinds of coagulant. In this study, the raw water was collected from the production lines of hydraulic looms. Jar tests with five batches of raw water were conducted at a fixed alum dosage of $\mathrm{Al}_{2}\left(\mathrm{SO}_{4}\right)_{3}, \mathrm{FeSO}_{4}, \mathrm{FeCl}_{3}$ and $\mathrm{PAC}, \mathrm{PFC}$. Samples were collected from about 2 $\mathrm{cm}$ below the surface and measured the $\mathrm{COD}_{\mathrm{Cr}}$ and turbidity removal for different kinds of coagulant.

Optimal dosage of coagulant. Coagulation-flotation tests were conducted at dosage of 50, 100, $150,200,250$ and $300 \mathrm{mg} / \mathrm{L}$, to ascertain the optimum dosage for particles and organic matter removal under the optimum coagulant, which had been chosen in prior studies.

Optimal dosage of ozone. Batches tests were conducted at dosage of 5, 10, 15, 20, 25, 30 and 35 $\mathrm{mg} / \mathrm{L}$ ozone, to ascertain the optimum dosage for particles and organic matter removal.

Water quality analysis. Chemical oxygen demand (COD) was measured with potassium dichromate method according to standard GB 11914-89. Ammonia nitrogen was measured with Nessler reagent according to standard GB 7479-87. Particles removal was measured with a HACH $2100 \mathrm{P}$ turbidimeter. And the measuring method of chroma was method of dilution multiple.

\section{Results and discussion}

Water quality characteristics of wastewater. The distribution of $\mathrm{COD}_{\mathrm{Cr}}$ in the suspended state, mesocolloid and the dissolved organics is showed in Table 2 and Fig. 2.

Table 2 The distribution of $\mathrm{COD}_{\mathrm{Cr}}$ in the suspending, mesocolloid and the dissolved organics of hydraulic loom wastewater

\begin{tabular}{ccccc}
\hline Indicators & $\begin{array}{c}\text { Total } \\
\mathrm{COD}_{\mathrm{Cr}}\end{array}$ & $\begin{array}{c}\text { Suspending } \\
\mathrm{COD}_{\mathrm{Cr}}\end{array}$ & $\begin{array}{c}\text { Mesocolloid } \\
\mathrm{COD}_{\mathrm{Cr}}\end{array}$ & $\begin{array}{c}\text { Dissolved } \\
\mathrm{COD}_{\mathrm{Cr}}\end{array}$ \\
\hline $\begin{array}{c}\text { Concentratio } \\
\mathrm{n}\end{array}$ & $214.0 \mathrm{mg} / \mathrm{L}$ & $67.5 \mathrm{mg} / \mathrm{L}$ & $100.3 \mathrm{mg} / \mathrm{L}$ & $45.2 \mathrm{mg} / \mathrm{L}$ \\
\hline
\end{tabular}

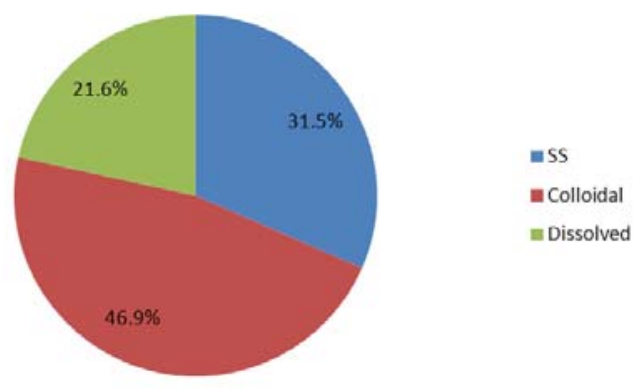

Fig. 2 Proportion of each state in the total $\mathrm{COD}_{\mathrm{Cr}}$ of hydraulic loom wastewater 
In table 2 and Fig.2, the concentration of suspending $\mathrm{COD}_{\mathrm{Cr}}$ is $67.5 \mathrm{mg} / \mathrm{L}$, accounting for $31.5 \%$; the mesocolloid of $\mathrm{COD}_{\mathrm{Cr}}$ is $100.3 \mathrm{mg} / \mathrm{L}$, accounting for $46.9 \%$; the content of dissolved $\mathrm{COD}_{\mathrm{Cr}}$ was $45.2 \mathrm{mg} / \mathrm{L}$, accounting for $21.6 \%$. Most $\mathrm{COD}_{\mathrm{Cr}}$ materials exist in mesocolloid and suspending form. In the selection of the advanced treatment process of hydraulic loom wastewater, the removal efficiency of mesocolloid and suspending organic pollutants should be selected.

Removal effect of the different kinds of coagulants on hydraulic loom wastewater. Use the same concentration of $\mathrm{Al}_{2}\left(\mathrm{SO}_{4}\right)_{3} 、 \mathrm{FeSO}_{4} 、 \mathrm{FeCl}_{3} 、 \mathrm{PAC}$ and $\mathrm{PFC}$ in hydraulic loom wastewater by coagulation-air flotation processing, and coagulant dosage was $200 \mathrm{mg} / \mathrm{L}$.

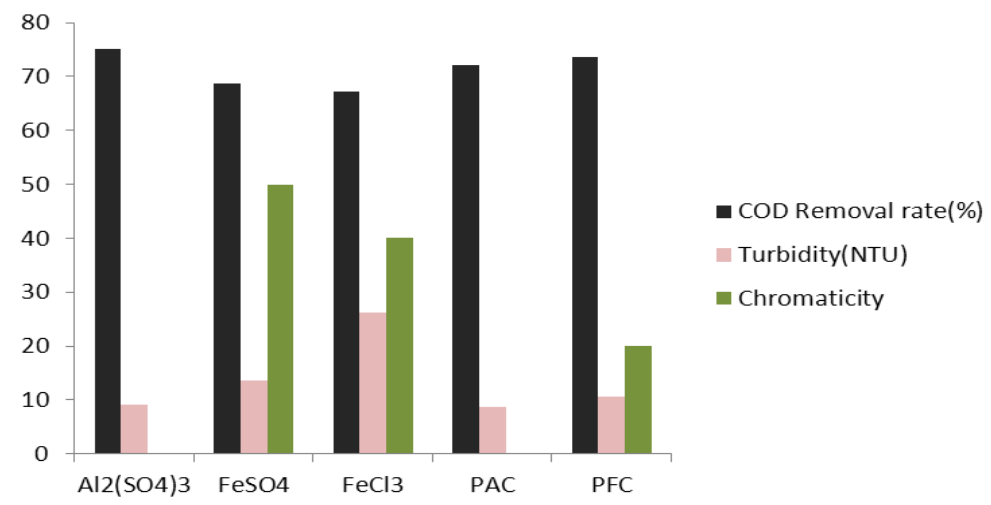

Fig.3 Different coagulants for hydraulic loom wastewater treatment effect

As shown in Fig.3: the best effect of the wastewater treatment was $\mathrm{Al}_{2}\left(\mathrm{SO}_{4}\right)_{3}$ which the $\mathrm{COD}_{\mathrm{Cr}}$ removal rate was as high as $75.1 \%$, and the second was $\mathrm{PFC}$ which the removal rate of $\mathrm{COD}_{\mathrm{Cr}}$ was $73.6 \%$, and the worst was $\mathrm{FeCl}_{3}$ which the removal rate was $67.2 \%$. The effluent turbidity using PAC was the lowest, which was $8.8 \mathrm{NTU}$, and then the followed was $\mathrm{Al}_{2}\left(\mathrm{SO}_{4}\right)_{3}$, which was $9.1 \mathrm{NTU}$. Three kinds of iron coagulant that were $\mathrm{FeSO}_{4}, \mathrm{FeCl}_{3}$ and $\mathrm{PFC}$ increased the chromaticity of wastewater. The chromaticity of the effluent using $\mathrm{FeSO}_{4}$ was the highest,which was 50 times. Two kinds of aluminum coagulant didn't produced chromaticity. It can be seen that $\mathrm{Al}_{2}\left(\mathrm{SO}_{4}\right)_{3}$ is the most suitable coagulant for the process by comparison.

Removal effect of the coagulant dosage on hydraulic loom wastewater.Use the different concentration of $\mathrm{Al}_{2}\left(\mathrm{SO}_{4}\right)_{3}$ in hydraulic loom wastewater by coagulation-air flotation processing, and selected the best dosing quantity.

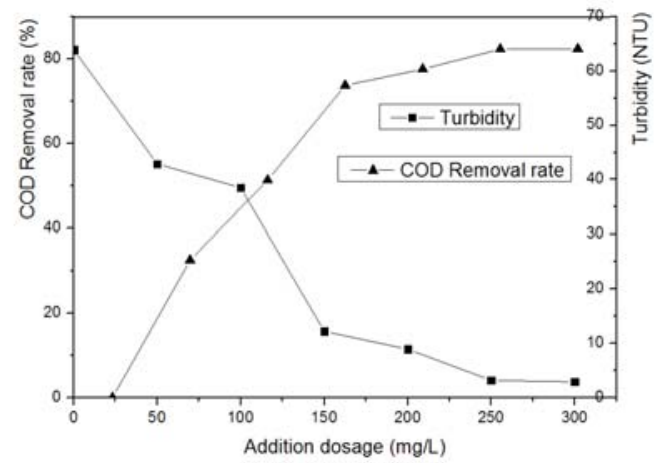

Fig.4 Different concentrations of $\mathrm{Al}_{2}\left(\mathrm{SO}_{4}\right)_{3}$ for hydraulic loom wastewater treatment effect

As shown in Fig. 4: with the increasing of $\mathrm{Al}_{2}\left(\mathrm{SO}_{4}\right)_{3}$ 's concentration, the effluent removal rate of $\mathrm{COD}_{\mathrm{Cr}}$ was significantly increased, and turbidity was significantly decreased. When the concentration of $\mathrm{Al}_{2}\left(\mathrm{SO}_{4}\right)_{3}$ reached $150 \mathrm{mg} / \mathrm{L}$, the removal rate of $\mathrm{COD}_{\mathrm{Cr}}$ increased slowly. When the concentration was $250 \mathrm{mg} / \mathrm{L}$, the removal rate of $\mathrm{COD}_{\mathrm{Cr}}$ reached $82.3 \%$, and the turbidity decreased from 63.9 NTU down to 3.2 NTU.When it continued to improve the concentration of $\mathrm{Al}_{2}\left(\mathrm{SO}_{4}\right)_{3}$, the removal effect of wastewater is not obvious.

Removal effect of the ozone dosage on hydraulic loom wastewater. When the concentration of $\mathrm{Al}_{2}\left(\mathrm{SO}_{4}\right)_{3}$ was $250 \mathrm{mg} / \mathrm{L}$, the removal effect of the different ozone dosage on Coagulation - Ozone flotation process was investigated, and the results of this study were shown in Fig.5. 


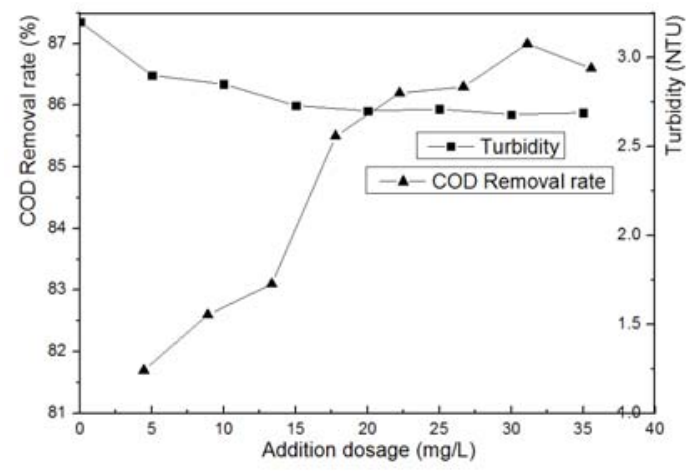

Fig.5 Different concentrations of ozone for hydraulic loom wastewater treatment effect

As shown in Fig.5, when ozone was pumped into the wastewater in the coagulation flotation, it would improve the removal effect of $\mathrm{COD}_{\mathrm{Cr}}$ effectively. When the concentration of ozone reached $20 \mathrm{mg} / \mathrm{L}$, the removal effect of $\mathrm{COD}_{\mathrm{Cr}}$ increased fastestly, which was from the original $81.7 \%$ to $86.2 \%$, and increased by $4.4 \%$. When the concentration of ozone was $30 \mathrm{mg} / \mathrm{L}$, the removal effect of $\mathrm{COD}_{\mathrm{Cr}}$ was the highest,up to $87.0 \%$. When the concentration of the influent $\mathrm{COD}_{\mathrm{Cr}}$ was $214 \mathrm{mg} / \mathrm{L}$, the effluent $\mathrm{COD}_{\mathrm{Cr}}$ could be reduced to $27.8 \mathrm{mg} / \mathrm{L}$. When continued to increase the concentration of ozone, the effluent $\mathrm{COD}_{\mathrm{Cr}}$ was on the rise. At the same time, turbidity also had a certain decline after ozone bubbled into, the effluent turbidity could decreased to 2.5 NTU. It would improve the clarity of the water, and also it was conducive to sterilization and recycle.

\section{Conclusions}

The characteristic of $\mathrm{COD}_{\mathrm{Cr}}$ distribution in hydraulic loom wastewater was investigated in this study. The results show that most of $\mathrm{COD}_{\mathrm{Cr}}$ materials exist in mesocolloid and suspending forms. Suspending and mesocolloid organics accounted for $31.5 \%$ and $46.9 \%$ of the total $\mathrm{COD}_{\mathrm{Cr}}$, respectively. The hydraulic loom wastewater was treated by the method of coagulation- ozonationflotation process, the best coagulant and dosage were screened, and ozone dosage was confirmed in the process. The results show that $\mathrm{Al}_{2}\left(\mathrm{SO}_{4}\right)_{3}$ is the most suitable coagulant for the process by comparison. The optimal dosage of $\mathrm{Al}_{2}\left(\mathrm{SO}_{4}\right)_{3}$ is $250 \mathrm{mg} / \mathrm{L}$, in which conditions the removal efficiency of $\mathrm{COD}_{\mathrm{Cr}}$ can reach to $87.0 \%$, and the turbidity decreased from $63.9 \mathrm{NTU}$ down to $3.2 \mathrm{NTU}$. When the concentration of ozone reached $30 \mathrm{mg} / \mathrm{L}$, the $\mathrm{COD}_{\mathrm{Cr}}$ and turbidity of influent were $214 \mathrm{mg} / \mathrm{L}$ and 63.9NTU, the corresponding effluent indexes can be reduced to $27.8 \mathrm{mg} / \mathrm{L}$ and $2.5 \mathrm{NTU}$, and the turbidity removal rate was $96.1 \%$. In this experiment, ozone oxidation can further reduce the $\mathrm{COD}_{\mathrm{Cr}}$ of effluent and the wastewater was sterilized at the same time. Ozone can react with hydrophilic colloid and process removing ability of flocculation air floatation process was enhanced .

\section{References}

[1]Yingzhi Lv,Zheng Sun,Zhenshan Zhi. Shandong textile technology. 6:52-53.(2005) In Chinese.

[2]Zheping Shen,Rongwu Mei,Yanfei Wei.Water \& Wastewater Engineering,11:65-68.(2012) In Chinese.

[3] Yuqin Mao,Xiaomao Wang,Hongwei Yang.etal. Chemosphere,117: 515-520.(2014)

[4]Bin Jiang.Industrial Water Treatment,32:84-86.(2012) In Chinese.

[5]Donglin Lai,Lv Zhou,Tao Li.Chinese Journal of Environmental Engineering,6:3861-3866 (2012)In Chinese. 